\title{
Epistemologi Etika Perdagangan Internasional Dalam Konsep Alquran
}

\author{
Hakim Muda Harahap \\ STAI-Barumun Raya, Sibuhuan, Sumatera Utara \\ hakimmuda0540@gmail.com
}

DOI: http://dx.doi.org/10.29240/alquds.v3i2.1148

Submitted: 2019-09-20 | Revised: 2019-10-20 | Accepted: 2019-11-06

\begin{abstract}
Classical and contemporary interpreters such as al-Thabari, Ibnu Katsir, alZamakhsari, al-Maraghi, al-Zuhaili and Sayyid Quttb believe that surah Quraish is one of the verses among other verses wich proves the existence of international trade practices with all its provisions, both law, system and ethics. The presence of term attijarah with term al-ba'i and isytara is common nakirah isim which is not related to any particular trade context activy. This indicates that anything related to trade in general in the Koran is itself related to international trade. This article aimed to explore how the relevance of international trade ethics in the Quran. The reseach is a library research by using maudhu'i interpretation approach. The results showed that international trade etich in the Koran concept wich both display the concepts of: a) actualization of religious spiritual intelligence by aligning intentions, strong intelligence an aqility, balance of heart and mind, honesty and responsibility; b) commodity exports and imports of halal products; c) prevention of bribery and corruption in international trade; d) prevention of usury practice in international trade: e) perfecting the scales and measurements in international trade; $\mathrm{f}$ ) prevention of the hoarding of goods in international trade; $\mathrm{g}$ ) the application of shari'ah accounting in international trade; $h$ ) preventing of prohibited commodity trading practice
\end{abstract}

Keywords: Maudhu'i's, Trade, Ethics, International Trade

\begin{abstract}
Abstrak. Para pakar tafsir klasik maupun kontemporer seperti al-Thabari, Ibnu Katsir, al-Zamakhsari, al-Maraghi, al-Zuhaili dan Sayyid Quthb meyakini bahwa surah Quraisy merupakan salah satu ayat di antara ayat lainnya yang membuktikan adanya praktek perdagangan internasional dengan seluruh ketentuannya, baik hukum, sistem maupun etikanya. Kehadiran terma at-tijara dengan terma al-bai' dan isytara merupakan isim nakirah yang bersifat umum yang tidak terkait kepada sesuatu kegiatan konteks perdagangan tertentu. Ini menandakan apa saja yang terkait dengan perdagangan secara umum dalam Alquran dengan sendirinya sudah terkait dengan perdagangan internasional. Tulisan ini mencoba nenelusuri bagaimana etika perdagangan internasional dalam Alqur'an.Penelitian ini adalah penelitian kepustakaan dengan menggunakan pendekatan tafsir maudhu'i. Hasil penelitian menunjukkan bahwa etika
\end{abstract}


perdagangan internasional dalam konsep Alquran menampikan konsep: a) aktualisasi kecerdasan spritual keagamaan dengan cara meluruskan niat, kuat cerdas dan cekatan, keseimbangan hati dan pikiran, kejujuran dan tanggung jawab; b) komoditas ekspor dan impor produk halal; c) pencegahan suap menyuap dan korupsi dalam perdagangan internasional; d) pencegahan praktik riba dalam perdagangan internasional; e) penyempurnaan timbangan dan takaran dalam perdagangan internasional; $f$ ) pencegahan penimbunan barang dalam perdagangan internasional; g) penerapan akuntansi syari'ah dalam perdagangan internasional; h) pencegahan praktik perdagangan komoditas yang terlarang.

Kata Kunci: Tafsir Maudhu'i, Perdagangan, Etika, Internasional

\section{Pendahuluan}

Perdagangan merupakan kegiatan manusia dalam mengolah sumber daya barang dan jasa untuk didistribusikan guna memenuhi kebutuhan dan keinginan masyarakat untuk memperoleh keuntungan. ${ }^{1}$ Perdagangan dibagi kepada dua macam, yaitu perdagangan dalam negeri yang dikenal dengan istilah perdagangan domestik dan perdagangan luar negeri yang dikenal dengan istilah perdagangan internasional. ${ }^{2}$ Dalam kegiatan perdagangan domestik tidaklah banyak ditemukan sengketa dan pelanggaran, karena hukum, budaya dan etika yang mendasari prinsip perdagangan dalam negerinya adalah berdasarkan hukum yang ditetapkan oleh negaranya masing-masing. Berbeda keadaan yang terjadi dalam praktek perdagangan internasional. Kegiatan perdagangan internasional yang melibatkan dua negara atau lebih itu ternyata di dalamnya menimbulkan berbagai macam permasalahan. Hal ini merupakan sesuatu yang tidak bisa dihindarkan, karena setiap negara pasti mempunyai konsep hukum, budaya dan etika yang melandasi aturan-aturan perdagangannya. ${ }^{3}$ Masing-masing negara pasti berpihak dan harus tunduk kepada sistem hukum yang ditetapkan oleh negaranya sendiri. Perbedaan sistem aturan hukum inilah yang menghambat dan menimbulkan masalah dalam perdagangan internasional. ${ }^{4}$

Negara-negara di dunia telah berupaya membuat suatu lembaga keuangan dunia dan organisasi perdagangan internasional untuk menyatukan perbedaan prinsip perdagangannya dalam sebuah bingkai aturan yang luas yang

${ }^{1}$ Emi R. Emawan, Business Etbics (Etika Bisnis), (Bandung: Penerbit Alfabeta, 2007), h. 11. Lihat juga T.S.G. Mulia, Perniagaan Luar Negeri: Teori dan Prakteknya, Jakarta: Dinas Penerbitan Balai Pustaka, 1958), h. 9.

${ }^{2}$ Franklin R. Root, Internastional Trade and Investment: Theory Policy Enterprise, (Brighton England: South-Western Publisihing, 1973), h. III.

${ }^{3}$ Howard S. Ellis dan Llyod S, Metzler, Reading in The Theori Of International Trade, (London: George Allen and Unwin, 1950), h.204-212.

${ }^{4}$ Ana Marcedes Lopez Rodriquez, "Lex Mercatoria", 2 Retzvidenskabeligt Tidskrit, (Argang: Juridiks Insititut Aarhus Universitet, 2002), h. 47. 
dapat berlaku bagi semua negara yang terlibat dalam perdagangan dunia. Terbentuknya organisasi Bank Dunia (The World Bank), ${ }^{5}$ Dana Moneter Internasional (The International Monetery Fund/ IMF), ${ }^{6}$ Organisasi Perdagangan Internasional (International Trade Organization/ ITO), Perjanjian Umum mengenai Perdagangan dan Tarif (General Agreement Trade and Tariffl GATT), ${ }^{7}$ dan Organisasi Perdagangan Dunia (The World Trade Organization/ WTO), ${ }^{8}$ merupakan usaha-usaha negara di dunia untuk menjembatani perbedaan prinsip perdagangannya. Sejak pendiriannya, banyak negara-negara di dunia yang berhasil dalam permufakatan perdagangan internasionalnya.Namun walaupun demikian, organisasi-organisasi dunia tersebut tetap saja belum dapat menghambat terjadinya sengketa dan konflik perdagangan.

Sepanjang abad 19 sampai abad 21, ada banyak kasus sengketa perdagangan internasional yang melibatkan dua negara atau lebih.Selain kasus sengketa, yang paling membahayakan bagi sisi kemanusiaan adalah terjadinya pelanggaran etika perdagangan internasional.Ini yang menjadi fokus kajian penulis dalam tulisan ini. Pelanggaran etika yang terjadi di antaranya pemalsuan asal-usul barang komoditas ekspor maupun impor; perdagangan drug trafficking atau perdagangan narkotika dan obat-obatan terlarang; praktek dumping yaitu diskriminasi harga dimana harga ekspor barang sejenis lebih rendah dari pada pasar domestik; perilaku fraud; cyber crime; perdagangan manusia; dan perdagangan senjata ilegal. Terjadinya pelanggaran etika perdagangan internasional tersebut disebabkan salah satunya oleh ketidakpatuhan pelaku perdagangan dalam mengimplementasikan etika perdagangan internasional. ${ }^{9}$ Penerapan etika perdagangan internasional dapat menjamin stabilitas keberlangsungan perdagangan internasional yang adil dan menjunjung tinggi nilai-nilai kemanusiaan yang adil dan beradab.

Kehadiran Alquran dalam Islam menjadi pedoman bagi seluruh umat manusia.Sepanjang sejarah, Alquran tetap selalu digali kandungan hukum dan ketetapannya.Pakar Islam seperti Fazlurrahman, ${ }^{10}$ maupun non Islam seperti W. Montgomery mengakui bahwa salah satu gagasan terbesar Alquran adalah menawarkan konsep etika perdagangan. Adanya term-term perdagangan dalam

5 T. May Rudy, SH, Hubungan Internasional Kontemporer dan Masalah-masalab Global: Isu, Konsep, Teori dan paradigma, (Bandung: PT. Refika Aditama, 2003), h. 33.

${ }^{6}$ Ibid, h. 32.

7 James R. Markusen, dkk.,International Trade Theory and Evidence, (Singapore: McGrawHill, 1995), h. 3.

${ }^{8}$ Sutiarnoto, Hukum Penyelesaian Sengketa Perdagangan Internasional, (Medan: USU Press, 2016), h. 1.

${ }^{9}$ K. Bertens, Pengantar Etika Bisnis, cet.7, (Yogyakarta: Penerbit Kanisius, 2000), h.13.

${ }^{10}$ Fazlur Rahman, Islam, (Chicago: The University of Chicago Press, 1997), h. 33. 
Alquran seperti al-tijarah, al-bai, isytara dan term lainnya mengindikasikan adanya konsep etika perdagangan. Konsep etika perdagangan tawaran Alquran tentu memiliki sisi keumuman. Dengan pemikiran bahwa lafazh semisal at-tijarah yang bermaknaperdagangan mencakup perdagangan secara umum. Dalam arti tidak hanya mencakup perdagangan domestik, tetapi juga mencakup perdagangan internasional. Pemikiran ini tentu perlu dibuktikan kebenarannya. Maka tulisan ini akan melakukan pengujian atas kevalidan keumuman lafazh at-tijarah mencakup keseluruhan perdagangan dalam seluruh konteksnya. Jika terdapat keumuman lafazh at-tijarah, maka sudah tentu etika perdagangan konsep Alquran dapat diterapkan kepada konsep etika perdagangan internasional.

Tulisan ini berusaha untuk mengungkap etika perdagangan internasional dalam konsep Alqur'an.Pendekatan yang digunakan dalam penelitian ini adalah pendekatan tafsir maudhu'i. Pendekatan ini merupakan usaha yang dilakukan dalam memahami maksud yang termaktub dalam Alquran sesuai batas kemampuan. Penulis menelusuri dan mendalami ayat-ayat Alquran terkait dengan etika perdagangan internasional, lalu ditafsirkan merujuk kitab-kitab tafsir yang tersebut di atas. Makna-makna ayat dianalisis berdasarkan metode analisis tematik (maudhu' $)$, analisis isi, analisis komparatif, analisis reflektif-kritis.

Berdasarkan hasil kajian terdahulu dipahami bahwa penelitian yang fokus kajiannya terkait konsep etika perdagangan internasional konvensional yang diintegrasikan dengan etika perdagangan internasional berbasis Alquran belum ada yang melakukan.Menurut penulis, tulisan etika perdagangan internasional dalam konsep Alquran sangat mendesak untuk diungkapkan karena arus globalisasi dan liberalisasi perdagangan internasional yang sudah tidak bisa terbendung lagi.Oleh sebab itu, penyusun berkeyakinan penelitian ini cukup signifikan untuk dilanjutkan.

\section{Legitimasi Perdagangan Internasional dalam Alqur'an}

Secara tematis konsep term perdagangan internasional sama dengan konsep term perdagangan secara umum.Memang tidak ada term yang menunjukkan istilah perdagangan internasional secara langsung, namun secara etimologis term perdagangan yang diungkapseperti term at-tijara, al-bai' dan isytara merupakan isim nakirah yang bersifat umum yang tidak terkait kepada sesuatu kegiatan konteks perdagangan tertentu.Dalam artian terma-terma tersebut mencakup semua jenis perdagangan secara umum termasuk dalam hal ini perdagangan internasional. Termaat-tijarah seperti potongan ayat dalam surah an-nisa' ayat 29: الا ان تكون تجارة yang bergaris bawah mengandung makna umum karena lafaz tersebut isim nakirah yang dapat menerima alif dan lam. Sesuatu lafaz yang dapat menerima alif dan lam disebut isim nakirah. Isim nakirah digunakan untuk menunjuk kalimat secara umum, tidak menyebutkan secara langsung perdagangan dalam negeri maupun perdagangan internasional. Namun secara eksplisit, perdagangan internasional itu telah ada sejak zaman dahulu. 
Kalimat-kalimat yang menunjukkan 'amm dan khas, mujmal dan mubayyan dan mutlaq dan muqayyad memposisikan sebagai kitab al-buda yang perlu dipahami secara dinamis dan komprehensif.

Allah melaluisurah al-Jumu'ah (62): 10 mengisyaratkan adanya perdagangan internasional dengan memerintahkan hamba-hamba-Nya mencari rezeki dan karunianya di dalam negeri sampai ke luar negeri. Hal ini ditegaskan dalam tafsir al-Qurthubi. ${ }^{11}$ Ayat senada terdapat dalam surah al-Mulk (67): 15. Ayat lainnya dalam surah Fushshilat (41: 10). Di ayat ini al-Qurthubi mengutip pandangan Ikrimah dan Al-Dahhak bahwa Allah memberi rezeki kepada penduduknya dan apa yang sesuai untuk kehidupan mereka berupa perdagangan, pohon-pohon dan manfaat-manfaat yang ada pada setiap negeri yang mana Allah tidak menjadikannya di daerah lain, supaya sebagian dengan yang lainnya bisa saling menghidupi melalui perdagangan domestik maupun perdagangan internasional dan perjalanan dari satu negeri ke negeri lainnya. ${ }^{12}$ Demikian juga Imam al-Maraghi seorang mufassir kontemporer dari Mesir menafsirkan potongan ayat yang sama sebagai isyarat adanya perdagangan internasional. ${ }^{13}$

Isyarat lainmengenai eksistensi perdagangan internasional ditunjukkan dalam surah Quraisy (106): 1-4. Merujuk klasifikasinya adalah surah ini bagian dari Makkiyah. Posisi surah Makkiyah dalam Alquran diturunkan sebelum Nabi hijrah ke Madinah. Turunnya ayat berarti diawal mula kenabian Nabi Muhammad SAW. Hal ini menunjukkan bahwa kegiatan perdagangan internasional sudah lama menjadi tradisi di kalangan masyarakat suku Quraisy. Dalam ayat pertama disebutkan "Karena kebiasaan orang-orang Quraisy" menunjukkan adanya kebiasaan-kebiasaan suku Quraisy melakukan perjalanan luar negeri dalam rangka kegiatan perdagangan internasional.Suatu kebiasaan yang terjadi dalam masyarakat tertentu tidak mungkin terjadi setahun atau dua tahun sebelumnya.Kebiasaan yang dilakukan itu biasanya turun temurun.Para ahli tafsir, baik klasik seperti al-Thabari, Ibnu Katsir, al-Zamakhsari maupun kontemporer seperti al-Maraghi, al-Zuhaili dan Sayyid Quthb menyepakati perdagangan internasional musim dingin mengarah ke kawasan bagian Selatan, yakni Yaman dan Hadramaut. Yaman dan Hadramaut merupakan wilayah yang bersentuhan dengan laut. Adanya transaksi perdagangan internasional dengan bangsa lain, membuat orang di bagian Selatan berkembang pesat dan lebih dahulu menjelajah lautan berdagang ikut dalam dunia internasional. ${ }^{14}$ Kemudian

${ }^{11}$ Abi 'Abdillah Muhammad bin Ahmad bin Abi Bakar al-Qurthubi, al-Jami' Liabkam alQur'an, juz. 20, h. 476.

${ }^{12}$ Ibid, h. 395-396.

${ }^{13}$ Ahmad Musthafa al-Maraghi, Tafsir al-Maraghi, juz. 18, h.

${ }^{14}$ Philip K. Hitti, History of The Arabs, (Jakarta: Serambi, 2008), h. 39. 
dari Yaman ini menjadi pintu utama perdagangan internasional menuju kawasan Timur sampai ke India bahkan lebih jauh sampai ke daratan Tiongkok. Sedangkan musim panas mengarah daerah Syam. Selanjutnya dari Syam akan menjadi pintu utama perdagangan internasional menuju Mediterania, Barat sungai Eufrat, Utara gurun Arab dan Selatan pegunungan Taurus. Daerah ini pada masa sekarang meliputi Lebanon, Palestina dan Jordania. ${ }^{15}$

Philip K. Hitti dalam History of The Arabs menguatkan bahwa bangsa Arab sebagai pedagang yang melakukan hubungan internasional paling awal. Menurutnya, kawasan semenanjung Arab telah dikenal baik oleh bangsa Yunani dan Romawi karena lokasinya berada di jalur perdagangan mereka menuju India dan Cina. Karena lokasi yang strategis, Romawi selalu berkeinginan mengekspansi tanah Arab dengan tujuan untuk menguasai rute perjalanan dagang yang dimonopoli bangsa Arab, tetapi Romawi tidak mampu menguasai perdagangan orang-orang Arab. ${ }^{16}$ Mukhtar Yahya mengungkapkan bahwa bangsa Arab kuno telah menguasai jalur perdagangan internasional, di antaranya, Tadmur, Saba', Nabath, Himyar dan sebagainya. ${ }^{17}$

Kehidupan bangsa Arab yang sarat dengan perniagaan merupakan fakta sejarah yang tidak terbantahkan. Karena kondisi situasi wilayah yang kering, tandus dan penuh padang pasir dan bebatuan, membuat bangsa Arab cenderung melakukan perdagangan untuk menyelamatkan hidup dan memperoleh penghasilan. Keunggulan bangsa Quraisy sebagai penjaga Ka'bah memberikan tiga keuntungan, yaitu mempunyai pengaruh yang kuat atas suku-suku lain, posisi sentral yang memberikan kemudahan dalam membangun relasi dan wilayah Mekah yang bebas dari peperangan dan permusuhan pribadi menyebabkan posisi mereka terjamin dan terhindar dari bahaya dan rasa takut. ${ }^{18}$ Kondisi tersebut memberikan peluang kesempatan dalam kegiatan perdagangan untuk menjalin hubungan perdagangan internasional seperti Syiria, Irak, Yaman dan Ethiopia.Juga mereka dapat mengadakan kontak langsung dengan budaya dan peradaban dari berbagai negara sehingga lambat laun penduduk Mekah mampu meningkatkan pengetahuan, kecerdasan dan kearifannya. Mereka lebih unggul dan sulit ditandingi dari suku Arab lainnya. Suku Quraisy mengalahkan suku-suku Arab lainnya dalam bidang kekayaan dan kemakmuran.Lebih dari itu, Mekah dijadikan sebagai pusat perdagangan internasional yang paling penting dan berpengaruh di seluruh semenanjung

${ }^{15}$ M. A. S. Abdel Haleem, The Qur'an: A New Translation, (Oxford \& New York: Oxford University Press, 2005), h. 438.

16 Philip K. Hitti, History of The Arabs Tenth Edition, (New York: Macmillan and CO, 1970), h. 44.

${ }^{17}$ Mukhtar Yahya, Perpindahan-perpindahan Kekuasaan di Timur Tengah sebelum Labir Agama Islam, (Jakarta: Bulan Bintang, 1985), h.111-120

${ }^{18}$ Buchari Alma, Dasar-dasar Etika Bisnis Islam, (Bandung: Alfabeta, 2003), h. 3-6. 
Arabia. Ada beberapa tempat-tempat perdagangan di semenanjung Arabia yang biasa dikunjungi para pedagang internasional seperti furnatul jandal, musaqqar, subar, Daba, Subar, Aden, San'a, Rabiyah, Ukaz, Drul Majaz, Mina, Nazat dan Hijr. $^{19}$

Di era globalisasi seperti sekarang ini, perdagangan internasional merupakan kegiatan ekonomi yang tidak dapat terelakkan di dalam peningkatan perekonomian suatu negara. Tidak sedikit negara yang mengandalkan sektor ekspor dan impor baik berupa barang ataupun jasa dengan tujuan menumbuhkan perekonomian negara. Semua negara di dunia tidak ada yang mampu memenuhi kebutuhan penduduknya sendiri. Kebutuhan penduduk suatu negara bervariasi mulai dari bahan-bahan pakaian, bahan-bahan makanan, alat transportasi, alat tekelomunikasi dan lain sebagainya. Keterbukaan ekonomi dan pelaksanaan pembangunan yang lebih mengandalkan sektor ekspor dan impor menempatkan posisi perdagangan internasional pada tempat yang penting. Globalisasi di bidang ekonomi merupakan situasi dimana terjadi hubungan saling ketergantungan di antara negara-negara yang menyebabkan munculnya peluang dan tantangan yang bervariatif bagi masing-masing negara. Perkembangan perdagangan internasional menyebabkan terjadinya perubahan yang fundamental dalam tatanan perekonomian dunia. Perkembangan ini memotivasi suatu negara menyesuaikan kebijakan dan praktek perdagangannya khususnya dalam sektor ekspor dan impor. Hal yang paling urgen dari sebab adanya hubungan perdagangan bilateral antara suatu negara dengan negara lainnya memicu diperlukannya standar etika perdagangan internasional yang stabil dan berlaku secara umum untuk menjaga kelancaran dan standar keadilan dalam perdagangan internasional.

\section{Justifikasi Etika Perdagangan Internasional dalam Konsep Alqur'an}

Islam melalui isyarat Alqur'an menuntun manusia kepada konsep etika perdagangan internasional. Tuntunan konsep Alqur'an mengenai visi perdagangan sudah sangat jelas, yaitu perdagangan bukan semata-mata mencari keuntungan material sesaat melainkan mencari keuntungan immaterial yang secara hakikat berakibat baik tidak hanya kepada pedagang dan tetapi juga kepada konsumen. Alquran menjelaskan etika Alquran berlandaskan kepada tiga terma kunci utama, yaitu iman, Islam dan taqwa yang apabila diamati akan memperlihatkan makna yang identik. ${ }^{20}$ Term iman dari akar kata amn yang dasar

\footnotetext{
${ }^{19}$ Afzalurrahman, Muhammad sebagai Seorang Pedagang, h. 3.

${ }^{20}$ Fazlur Rahman, Metode dan Alternatif Neomodernisme Islam Fąlurrahman, Taufik Adnan Amal (Penyunting), (Bandung: Mizan, 1992), h. 66.
} 
artinya keamanan, bebas dari bahaya dan damai. Islam yang akar katanya dari salama juga berati aman, integral, terlindungi dari disintegrasi dan kehancuran. Term taqwa yang berakar kata waqa juga memiliki pengertian melindungi dari bahaya, menjaga kerusakan dan kemusnahan dan lain sebagainya. ${ }^{21}$ Ketiga term kunci etika Alquran tersebut merupakan refleksi secara langsung mengarahkan ke dalam bawah sadar Alquran sebagaimana adanya. Alquran memberikan kepada umat elan dasar Alquran. Elan dasar ini ditujukan untuk melindungi dan mengembangkan integritas seseorang atau orang banyak. Dalam pandangan ini, yang dianggap kondusif bagi integritas tersebut dipandang baik, dan apa saja menghalangi integritas dan membawa ke arah disintegrasi akan dipandang jelek. $^{22}$

Dalam era globalisasi ini, kegiatan perdagangan internasional muncul dengan persaingan ketat yang mengakibatkan nilai-nilai etika seringkali terabaikan. Untuk menghadapinya, Alquran perlu dihadirkan sebagai pedoman dalam perdagangan internasional. Alquran dipandang memiliki formulasi yang relevan pada setiap zaman. Dari sekian ayat-ayat Alquran, sebagiannya mendorong manusia untuk mencari rezeki yang berkah, melakukan produksi dan menekuni aktifitas ekonomi di berbagai bidang usaha seperti pertanian, industri, perdagangan, dan bidang-bidang lainnya. Alquran mendorong setiap perbuatan harus menghasilkan produk dan jasa yang bermanfaat bagi manusia dan mendatangkan kemakmuran dan kesejahteraan bersama. ${ }^{23}$

Adanya term-term at-tijarah, al-ba'I dan isytara dalam Alquran mengindikasikan adanya etika perdagangan internasional dalam konsep Alquran. Etika perdagangan internasional yang dimaksud tersurat dan tersirat dalam ayatayat yang mengungkap terma-terma perdagangan tersebut. Ada memang ayat yang konteksnya mengungkap etika perdagangan, tetapi tidak terdapat di dalamnya ketiga terma perdagangan tersebut. Untuk hal ini, penyusun akan menganalisis ayat yang dimaksud apabila ternyata mengungkap etika perdagangan tidak menutup kemungkinan dimasukkan dalam bagian etika perdagangan dalam konsep Alquran.

\section{Internalisasi nilai-nilai Spritual Keagamaan Islam}

Penerapan spritualitas dalam perdagangan menunjukkan kekuatan yang positif dalam segala kegiatannya. Perlunya pelaku perdagangan mengimplementasikan spritualitas Islam, tidak hanya berlaku kepada kegiatan perdagangan domestik saja, tetapi juga harus diterapkan kepada perdagangan

${ }^{21}$ Muhammad dan Alimin, Etika dan Perlindungan Konsumen dalam Ekonomi Islam, cet. 1, (Yogyakarta: BPFE, 2004), h. 48.

${ }^{22}$ Ibid.

23 "Dialah yang menjadikan bumi itu mudah bagi kamu, maka berjalanlah di segala penjurunya dan makanlah sebahagian dari rezki-Nya.dan hanya kepada-Nya-lah kamu (kembali setelah) dibangkitkan.” (QS. Al-Mulk (67): 15) 
internasional karena yang diperdagangkan adalah komoditas ekspor dan impor dimana peluang terjadinya kecurangan (fraud), kolusi, korupsi, penipuan dan rekayasa keuangan, lebih besar dibandingkan perdagangan domestik.

Ada sebagian orang berpendapat spritualitas tidak ada kaitannya dengan aktifitas perdagangan. Spritualitas keagamaan hanya berurusan dengan ritual ibadah mahdhah semata, ibadah hanya ada di tempat ibadah saja bukan di sentra-sentra perdagangan. Spritualitas hanya keterikatan individu secara penuh kepada Tuhan sebagai kreator yang diinternalisasikan dalam diri individu dan dimanifestasikan dalam perilaku keseharian. ${ }^{24}$ Spritualitas merupakan perilaku taat melaksanakan perintah Allah dan konsisten menjadikan wahyu Allah sebagai sumber inspirasi dalam pengembangan ilmu dan pelayanan.

Dikotomi antara spritualitas dan perdagangan ini menyebabkan keduanya seperti ada yang kurang. Spritualitas tanpa didukung oleh perekonomian yang cukup dapat menyebabkan keterbelakangan pelakunya di berbagai bidang karena hampir semua kegiatan hidup membutuhkan dukungan ekonomi. Sebaliknya perdagangan tanpa penyertaan nilai-nilai spritualitas menyebabkan ketidakpuasan dan kebingungan arah yang dituju. Dua kutub ekstrim ini seharusnya dapat bertemu dalam dunia perdagangan yang menerapkan nilai-nilai spritualitas di mana seolah-olah keduanya berjalan secara terpadu dan berkelindan.

Kemunculan termaat-tijarah dalam QS. Al-Baqarah (2): 282, QS. an-Nisa (4): 29, QS. al-Taubah (9): 24, QS. al-Nur (24): 37, QS. al-Jumu'ah (62): 11, QS. Fathir (35): 29 dan QS. Al-Shaf (61): 10 dan QS. al-Baqarah (2): $16,{ }^{25}$ menunjukkan bahwa perdagangan tidak hanya berkaitan dengan material semata, tetapi juga mengarah kepada hal-hal yang bersifat immaterial. Aktifitas perdagangan tidak hanya orientasinya untuk memperoleh kekayaan semata, tetapi juga harus berorientasi untuk belanja akhirat. ${ }^{26}$ Surah al-Jum'ah ayat 9 misalnya, panggilan spritual ketuhanan untuk menunaikan shalat adalah lebih baik dari perdagangan dan seluruh aktifitas mu'amalah. ${ }^{27}$ Kemudian ayat 10 menegaskan bahwa apabila shalat jum'at sudah ditunaikan, maka pedagang atau pelaku usaha mu'amalah lainnya dapat meneruskan perdagangannya dan

${ }^{24}$ Asy'ari, Religiusitas dan Cultural Belief dalam Perilaku Ekonomi Muslim Minangkabau di Sumatera Barat, Disertasi, Program Pascasarjana Doktor Ilmu Ekonomi Fakultas Ekonomi Universitas Andalas Padang, 2016, h. 18

${ }^{25}$ Muhammad Fu'ad Abd. Al-Baqi, Al-Mu'jam al-Mufahras Li Al-Faz̧h al-Qur'an al-Karim, (Qahirah: Dar al-Hadits, t.th.), h. 152.

${ }^{26}$ Qur'an Hafalan dan Terjemahannya, h. 554.

${ }^{27}$ Wahbah az-Zuhaili, at-Tafsir al-Munir fi al-'Aqidah wa asy-Syari'ah, wa al-Manhaj, jilid. I, h. 574. 
mengembangkan sayap-sayap perdagangan internasional di seluruh penjuru dunia dalam rangka mencari karunia Allah. ${ }^{28}$

Dari pemaparan di atas menunjukkan bahwa pertama, pengarusutamaan pengamalan spritualitas dan religiusitas lebih urgen dibandingkan urusan perdagangan dan seluruh urusan kegiatan mua'malah lainnya.Spritualitas lebih dominan daripada materialitas lainnya. Hal ini ditunjukkan oleh surah al-Jumu'ah ayat 9 dan 10 yang tersebut di atas; kedua, ketika menjalankan nilai-nilai spritualitas keagamaan seperti shalat dan lainnya jangan sampai terabaikan dengan urusan-urusan yang bersifat insidental sehingga mengacaukan kekhusukan dalam ibadah; ketiga setiap pelaku usaha dalam perdagangan internasional dengan seluruh yang melingkupinya harus mengutamakan nilainilai spritualitas keagamaan sekalipun disibukkan oleh kegiatan-kegiatan perdagangan.

Penerapan unsur-unsur spritualitas dalam perdagangan internasional menghantarkan hasil yang positif dalam kehidupan.Pedagang internasional yang menyandarkan aktifitasnya pada aspek spritualitas terbukti lebih mampu bertahan dan berkembang secara baik. Secara umum ada enam manfaat yang di dapat oleh para pedagang internasional bila menyandarkan perdagangan internasionalnya kepada aspek spritualitas, yaitu pertama, pedagang internasional akan terjauh dari perilaku kecurangan (fraud) yang mungkin saja terjadi akibat menghalalkan segala cara; kedua, dapat meningkatkan produktifitas dan kinerja pedagang internasional; ketiga, terbangunnya suasana kerja yang harmonis atau hadirnya sinergitas antara karyawan, pimpinan dan perusahaan; keempat, meningkatnya citra positif pedagang internasional; kelima, menghantarkan pedagang internasional tumbuh dan berkembang secara berkesinambungan (sustainable company); keenam, menurunkan perpindahan (turnover) para pembantu pedagang internasional.

\section{Penekanan Kehalalan Produk Ekspor dan Impor}

Dalam ekspor dan impor yang perlu ditekankan adalah kehalalan komoditas yang diperdagangkan.Langkah awal adalah pelabelan halal kepada produk atau kemasan pangan yang dapat menunjukkan bahwa produk atau kemasan itu telah menjalani proses pemeriksaan kehalalan dan telah dinyatakan halal secara syariat. Label halal memiliki fungsi utama yaitu untuk memberikan ketentaraman bagi umat Islam. Dengan adanya label halal, ternyata banyak dari konsumen lebih merasa aman dan lebih selektif dalam melakukan konsumsi beberapa produk yang beredar di pasaran.Allah mengarahkan manusia untuk

${ }^{28}$ Ibid,.h. 575. 
memperhatikan kehalalan makanan dan minuman. Al-Baqarah (2): 172-173,172 dan 173, al-Maidah (4): 3 dan ayat-ayat yang terkait dengannya. ${ }^{29}$

Permasalahan pangan sesungguhnya sudah lama dibahas pada setiap agama di dunia.Karena pangan merupakan alat berbagai ritual peribadatan dalam hal pembayaran zakat berupa makanan pokok daerah masing-masing, pemberian makanan bagi orang-orang fakir dan miskin dan sebagainya. Karena itu, agama menjadi penentu apakah sesuatu makanan boleh dikonsumsi atau tidak boleh, jenis atau kriteria makanan apa yang boleh dikonsumsi. Semakin banyak pemeluk agama, maka semakin besar pola konsumsi pangannya.Berkenaan dengan hal tersebut, perkembangan umat Islam yang besar ikut mempengaruhi sikap dan perilakunya sebagai konsumen.Semua agama turut ikut andil mengatur persoalan makanan, termasuk agama Islam.Islam memperkenalkan konsep balalan tayyiba dalam menetapkan standar kualtias untuk makanan dan minuman. Konsep ini belakangan disarikan menjadi Sistem Jaminan Halal $(\mathrm{SJH})$ yang dikembangkan oleh negara-negara yang berpenduduk mayoritas muslim. Persoalan yang membedakan Sistem Jaminan Halal dengan sistem kualitas yang lain bertitik tolak kepada kualitas itu sendiri. Dalam sistem kualitas konvensional, kualitas didefenisikan berdasarkan pada konsensus manusia, sementara sistem jaminan halal didasarkan kepada ajaran, Hadis, Qiyas dan Ijma' Ulama.

\section{Pencegahan Praktik Suap dan Korupsi}

Pelanggaran etikaperdagangan internasional yang juga sering terjadi adalah maraknya praktik suap menyuap dan korupsi. Dalam bahasa arab suap disinonimkan dengan kata رشا bermakna hadiah, komisi, pelicin atau suap. Kata رُ الرشوة رشاالفرخ اذا مد رأسه الى أمه لتزقه (burung itu merengek-rengek ketika mengangkat kepalanya kepada induknya untuk disuapi. ${ }^{30}$ Secara terminologis risywah merupakan sesuatu yang diberikan dalam rangka mewujudkan kemaslahatan atau sesuatu yang diberikan dalam rangka membenarkan yang batil atau menyalahkan yang benar. ${ }^{31}$ Risywah merupakan uang sogok yang sudah menjadi penyakit masyarakat dan tidak dibenarkan dalam syari'at Islam. ${ }^{32}$

${ }^{29}$ Wahbah az-Zuhaili, at-Tafsir al-Munir fi al-'Aqidah wa asy-Syari'ah, wa al-Manhaj, jilid. I, h. 444.

${ }^{30}$ Ibnu Manzhur, Lisan al-Arabi, (Kairo: Dar al-Ma'arif, t.th), h. 1653

${ }^{31}$ Nurul Irfan, Korupsi Dalam Hukum Pidana Islam, cet. 1, (Jakarta: AMZAH, 2011), h. 89

32 Abdul Aziz Dahlan, Ensiklopedia Hukum Islam, Jakarta: Ichtiar Baru Van Hoeve, 2003), h. 1506. 
Suap menyuap sudah cukup lama dikenal terutama ketika manusia bekerja dalam sebuah organisasi dan menghadapi tekanan atau hambatan dalam mencapai tujuan yang diinginkan.Dewasa praktik suap menyuap di semua sektor kehiduan sudah merupakan kebiasaan masyarakat luas seperti money politik, gratifikasi, pelicin, komisi, pungli dan lain-lain.Suap menyuap tidak hanya terjadi di sektor pemerintahan maupun di sektor swasta, tetapi juga merambat ke sektor perdagangan internasional. Kasus suap menyuap di sektor perdagangan internasional disebabkan dua faktor:

Pertama, faktor ketatnya kompetisi perdagangan.Dalam meningkatkan keunggulan bersaing dari pelaku pedagangan, perusahaan dan lainnya, mereka harus lebih efesien daripada pesaing. Untuk itu ada pelaku perdagangan internasional, perusahaan nasional atau perusahaan multinasional menyuap petugas pajak dengan tujuan mengurangi biaya pajak yang harus dibayarkan;

Kedua, faktor profit (keuntungan). Pedagang domestik atau pedagang internasional maupun perusahaan untuk memperoleh peluang memenangkan proyek pembangunan gedung, pengadaan peralatan kantor, dan sebagainya, mereka berupaya menyuap para pejabat berwenang membuat keputusan yang berkaitan dengan proyek-proyek tersebut. Di samping itu, dalam rangka meningkatkan keuntungan, pedagang internasional yang bergerak di bidang ekspor dan impor menyuap para pejabat yang berwenang dalam suatu negara agar komoditas barang impornya masuk ke suatu negara dengan kuota yang lebih besar, sehingga ia lebih leluasa memonopoli pengadaan barangnya. Seperti kasus suap menyuap penambahan kuota impor daging sapi PT. Indoguna Utama yang mengalir di tubuh salah satu partai terbesar di Indonesia.

Perilaku korupsi juga sering terjadi dalam perdagangan internasional. Untuk itu perlu adanya penekanan pentingnya pencegahan korupsi dalam kegiatan tersebut. Istilah mengenai tindakan-tindakan yang dipandang korupsi menurutSyamsul Anwar yaitu, akel al-mal bi al-bathil, ${ }^{33}$ al-ghulul, ${ }^{34}$ assubt. ${ }^{35}$ Sedangkan dalam hadis dikenal dengan istilah hadiah, Risywah dan ghulul. ${ }^{36}$

Praktik korupsi berkembang pada berbagai negara maju secara luas.Praktik ini tidak hanya terjadi di sektor pemerintahan atau publik, tetapi juga terjadi di sektor swasta, korporasi, perusahaan perdagangan domestik dan

${ }^{33}$ QS. Al-Baqarah (2): 188

${ }^{34}$ Ayat-ayat yang mengungkap kata tersebut seperti QS. Ali Imran (3): 161, QS. An-Nisa' (4): 171, QS. Al-Maidah (5): 64, QS. Al-A'raf (7): 43-158, QS. Ar-Ra'd (13): 5, QS. Al-Hijr (15): 47, QS. Al-Isra' (17): 29, QS. QS. Saba (34): 33, QS. Ghafir: 81, QS. Yasin (36): 8, QS. AshShaffat (37): 47, QS. Al-Mu'min (40): 71, QS. QS. Ad-Dukhan (44): 45-46, QS. Al-Hasyr (59): 10, QS. Al-Haqqah (69): 30, dan QS. Al-Insan (76): 4

${ }^{35}$ QS. al-Maidah (5): 42, 62 dan 63

36 Syamsul Anwar, "Korupsi dalam Perspektif Hukum Islam”, Jurnal Hukum, No. 1, Vol. 15, Januari, 2008, h. 14-31. 
perdagangan internasional.Seperti ungkapan George Moody Stuart selubung terbesar satu-satunya untuk korupsi dalam pengadaan barang ekspor dan impor antara perusahaan nasional maupun internasional adalah pemberian uang komisi, suap atau pelicin yang diberikan kepada pejabat publik. Pejabat itu bertugas untuk meluluskan kontrak perdagangan dimana disediakan dana yang cukup untuk melakukan itu, sedangkan perusahaan pengekspor tidak harus mengetahui dengan rinci apa yang dilakukan oleh pejabat negara itu. Dengan demikian tercipta sekat dan jarak aman antara perusahaan itu dan tindak korupsi yang memungkinkannya bisa terkejut apabila perbuatan tercela itu muncul ke permukaan. Cara ini juga memungkinkan pejabat bersangkutan mengantongi semua uang yang tersisa sesudah uang suap atau komisi dibayar semua.

\section{Pencegahan Praktek Riba}

Riba secara etimologis berarti tumbuh dan membesar. Sedangkan secara terminologis riba bermakna pengambilan tambahan dari harta pokok atau modal secara batil.Muhammad Syafi'i Antonio yang mengutip pendapat Ibn al-Arabi, yang dimaksud batil adalah tidak adanya transaksi pengganti atau penyeimbang dalam bisnis atau komersial yang melegitimasi adanya penambahan tersebut secara adil, seperti transaksi jual beli, gadai, sewa, atau bagi hasil proyek. ${ }^{37}$ Dalam transaksi yang bermuatan riba, dalam hal pinjam meminjam misalnya, peminjam menarik uang lebih dari uang yang dipinjamkan.Kelebihan itu dipandang batil atau riba, karena mendapatkannya tanpa ada penyeimbang, pengganti, atau resiko yang harus ditanggung peminjam. Tidak adanya penyeimbang, pengganti, atau resiko yang harus ditanggung menyebakan transaksi pinjam meminjam menjadi cacat dan tidak adil, karena itulah Allah mengharamkannya.

Perdagangan ini memerlukan modal besar untuk memproduksi barangbarang yang akan diperdagangkan di tingkat internasional. Kondisi ini menyebabkan orang-orang yang terkait dengan perdagangan internasional baik produsen, importir, eksportir dan sebagainya terganjal modal. Maka mereka ini tidak dapat tidak harus meminjam uang modal yang lebih besar agar tujuan yang dimaksud tercapai. Hal yang harus dihindari oleh pedagang dalam hukum Islam melanggar ketentuan-ketentuan hukum Islam. Pedagang internasional harus menghindari praktik-praktik riba. Riba bisa terjadi ketika pedagang meminjam uang untuk modal dan pengembaliannya sesuai waktu yang ditentukan dan pengembaliannya harus dilebihkan dari jumlah modal yang dipinjam. Riba merupakan transaksi haram dan termasuk dosa besar. Pelaku riba mendapatkan laknat dari Allah dan dijauhi dari rahmat-Nya.Riba dikategorikan sebagai dosa besar. Larangan riba mempunyai empat maqashid syariah, yaitu pertama, uang

${ }^{37}$ Muhammad Syafi'i Antoni, Bank Syari'ah, dari Teori ke Praktek, (Jakarta: Gema Insani, Press, 2001), h. 37 
tidak boleh menjadi komoditas yang diperdagangkan sehingga uang tidak dapat melahirkan uang, tetapi uang semestinya fungsinya menjadi alat tukar dalam sirkulasi barang dan jasa; kedua di dalam riba qardh, keuntungan muncul tanpa adanya resiko, hasil usaha muncul tanpa adanya biaya. Dalam bahasa lain keuntungan dan hasil usaha diperoleh dengan cara menunggu berjalannya waktu; ketiga, riba jahiliyyah dilarang karena terjadi pelanggaran kaidah setiap pinjaman yang memberikan manfaat kepada kreditor adalah riba; keempat, melakukan pencegahan terhadap riba mencegah rentenir berbuat zhalim kepada penerima pinjaman karena adanya praktik riba berarti pemberi pinjaman mengeksploitasi penerima pinjaman dengan meminta bunga atas pinjaman yang diberikan. ${ }^{38}$

\section{Penerapan Kesetaraan Timbangan dan Takaran}

Dalam perdagangan internasional untuk membangun kerangka kepercayaan bagi seorang pedagang atau pengusaha di level internasional harus berbuat jujur atau adil, baik terhadap dirinya maupun terhadap orang lain. Sikap jujur harus diwujudkan misalnya, kepada praktik penggunaan timbangan yang tidak membedakan antara kepentingan penjual maupun pembeli. Dengan sikap jujur seorang pedagang, maka kepercayaan pembeli akan tercipta dengan sendirinya.

Hal yang perlu diperhatikan dalam peragangan internasional adalah memperhatikan prinsip etika perdagangan yang digariskan dalam Islam, yaitu: Pertama, pelaku perdagangan internasional harus menerapkan sikap kejujuran dalam takaran dan timbangan (quantity). Jujur dalam takaran dan timbangan merupakan hal yang urgen untuk diperhatikan karena Allah memberi ancaman keras kepada pedagang-pedagang yang tidak berlaku jujur; Kedua, menjual barang yang baik mutunya (quality). Salah satu persoalan yang tidak etis dalam perdagangan adalah tidak transfaran dalam permasalahan mutu sehingga mengabaikan tanggung jawab moral dalam perdagangan. Padahal tanggung jawab yang diharapkan adalah tanggung jawab yang berkesimbangan (balance) antara mendapatkan keuntungan (profit) dan memenuhi norma-norma dasar masyarakat baik berupa hukum maupun etika dan adat. Sesuatu yang hanya sekedar mengejar keuntungan dengan mengurangi mutu, identik dengan ketidakjujuran, sehingga secara langsung telah menindas orang lain. Penindasan amat bertentangan dengan agama Islam, karena merupakan perbuatan zhalim. ${ }^{39}$

Dalam perdagangan internasional, persaingan merupakan hal yang wajar bahkan dapat disebut sebagai suatu yang esensial.Para pelaku perdagangan berkompetisi menelurkan inovasi-inovasi baru guna menunjang meningkatkan

38 Adiwarman A. Karim dan Oni Sahroni, Riba, Gharar dan Kaidah-kaidah Ekonomi Syari'ab: Analisis Fikib dan Ekonomi, (Jakarta: Raja Grafindo Persada, 2015), h. 13.

${ }^{39}$ Muhammad Djakfar, Etika Bisnis Menangkap Sprit Ajaran Langit dan Pesan Moral Ajaran Bumi, cet. 1, (Jakarta: Penebar Plus, 2012), h. 44. 
pangsa pasar dunia.Akan tetapi hal ini tidak jarang menimbulkan suatu tindakan yang kurang baik yang lazim disebut dengan persaingan yang tidak sehat. Persaingan yang tidak sehat atau unfair trade practice merupakan persaingan antar pelaku perdagangan dengan cara tidak jujur atau bahkan melawan hukum untuk menghambat persaingan perdagangan yang berdampak negatif terhadap dunia perdagangan. Salah satu tindakan yang kerap kali disebut sebagai unfair trade practice di dunia perdagangan internasional adalah dumping. Dalam perspektif General Agreement on Tariffs and Trade (GATT) bentuk umum unfair trade practice yang dipersoalkan adalah masalah dumping. ${ }^{40}$ Hal ini dikarenakan dumping dapat mengakibatkan kerugian yang luas terhadap produsen yaitu menyempitnya pangsa pasar produsen dalam hal ini yang dimaksud adalah negara tuan rumah. Dumping juga memberikan dampak negatif bagi usahausaha mikro di negara importir terlebih bagi negara-negara importir yang masih termasuk dalam kualifikasi negara berkembang.Karena dampak negatif dari tindakan dumping tersebut maka disusunlah suatu langkah untuk menanggulanginya yaitu kebijakan anti-dumping.Kebijakan ini dibuat dalam bentuk code yang dibentuk selama Kennedy Round (1962-1967) yang merupakan penjabaran dari Pasal VI GATT. Anti-dumping pada kenyataannya tidak selalu diberlakukan sebagaimana mestinya, akan tetapi sering dipergunakan sebagai perisai untuk sekedar melindungi pasar domestiknya.

\section{Penerapan Akuntansi Syari'ah dalam Ekspor dan Impor}

Dalam sejarah Islam ditemukan bahwa setelah munculnya Islam di semanjung Arab dan terbentuknya pemerintahan Islam di Madinah dari mulai Nabi Muhammad hingga zaman Khulafaurrasyidin, terdapat undang-undang akuntansi yang diterapkan untuk perorangan, perserikatan atau perusahaan, akuntansi wakaf, hak-hak pelarangan dan penggunaan harta dan anggaran negara. Rasulullah pada masa itu telah mendidik secara khusus beberapa sahabat untuk menangani profesi akuntan dengan sebutan hafarhatul amwal (pengawas keuangan). Allah menganggap akuntansi ini penting sehingga diturunkan sebuah ayat Alquran terpanjang, yakni al-Baqarah (2): 282 yang menjelaskan fungsifungsi pencatatan transaksi, dasar-dasarnya, manfaat-manfaatnya. ${ }^{41}$

Dalam perdagangan internasional, penulisan administrasi pembukuan dalam seluruh aspek sangat dibutuhkan guna menghindari terjadinya sengketa perdagangan internasional.Banyak kasus permasalahan yang terjadi dalam perdagangan internasional diakibatkan lemahnya akuntansi pembukuannya. Dalam konteks ini kalangan pemerhati perdagangan internasional

${ }^{40}$ Ida Bagus Wyasa Putra, Aspek-aspek Hukum Perdata Internasional Dalam Transaksi Bisnis Internasional, (Bandung: Refika Aditama, 2008), h. 11

${ }^{41}$ Sofyan Syafri Harahap, Akuntansi Islam, (Yogyakarta: Bumi Aksara, 2004), h.42 
mempopulerkan istilah akuntansi internasional. Akuntansi internasional adalah akuntansi untuk tranksaksi internasional, perbandingan prinsip di negara-negara yang berbeda dan harmonisasi berbagai standar akuntansi. Peningkatan perdagangan internasional dapat memfasilitasi perluasan pergerakan barang dan jasa serta meningkatkan efesiensi penggunaan sumber-sumber ekonomi. Akuntansi harus berkembang agar mampu memberikan informasi yang diperlukan dalam pengambilan keputusan di perusahaan pada setiap perubahan lingkungan perdagangan internasional. Perbedaan akuntasi internasional adalah pada pelaporan untuk MNC/ MNE. Batas negara, pelaporan untuk pihak lain di negara yang berbeda, perpajakan internasional dan transaksi internasional. Dalam akuntansi internasional terdapat tiga proses akuntansi, yaitu pertama, pengukuran, yakni proses pengelompokan dan penghitungan aktifitas ekonomi dan transaksi serta memberikan masukan mendalam mengenai profitabilitas dan operasi; kedua, pengungkapan, yakni proses pengkomunikasian kepada para pengguna; ketiga, auditing, yakni proses atestasi terhadap keandalan pengukuran dan komunikasi.

\section{Penutup}

Terungkaplah dalam Alquran bahwa legitimasi ayat-ayat yang berkaitan dengan at-tijarah dengan al-bay' dan isytara sudah jelas. Tujuan at-tijarah adalah tidak hanya bertujuan material jangka pendek semata, tetapi juga jangka panjang immaterial sampai menuju alam akhirat. Perdagangan tidak hanya berhubungan dengan manusia semata, tetapi juga harus membangun hubungan manusia dengan Allah. Oleh sebab itu, konsep perdagangan Alquran baik aktifitasnya maupun komoditas barang yang diperdagangkan harus berdasarkan ketentuan Allah dan Rasul-Nya. Bahkan laba dan keuntungan pun harus diperoleh dengan cara-cara yang tidak melanggar ketentuan syari'ah.

Secara tematis dapat dijustifikasi bahwa konsep term perdagangan internasional dalam Alquransama dengan konsep term perdagangan secara umum.Memang tidak ada term yang menunjukkan istilah perdagangan internasional secara langsung dalam Alquran, namun secara etimologis term perdagangan yang diungkap Alquran seperti term at-tijara, al-bay' dan isytara merupakan isim nakirah yang bersifat umum yang tidak terkait kepada sesuatu kegiatan konteks perdagangan tertentu. Dalam artian term-term tersebut mencakup semua jenis-jenis perdagangan secara umum termasuk dalam hal ini perdagangan internasional.

Etika perdagangan internasional dalam konsep Alquran yaitu, a). Internalisasi spritual keagamaan; b) penekanan kehalalan produk ekspor dan impor, c) pelarangan suap dan korupsi; d) pencegahan praktik riba; e) kesetaraan timbangan dan takaran, f) penerapan akuntansi syari'ah dalm ekspor dan impor. 


\section{Bibliografi}

Abdel Haleem, M. A. S.The Qur'an: A New Translation, Oxford \& New York: Oxford University Press, 2005.

Antoni,Muhammad Syafi'i, Bank Syari'ah, dari Teori ke Praktek, Jakarta: Gema Insani, Press, 2001.

Al-Baqi, Muhammad Fu'ad Abd.Al-Mu'jam al-Mufahras Li Al-Faz̧ al-Qur'an alKarim, Qahirah: Dar al-Hadits, t.th.

Buchari Alma, Dasar-dasar Etika Bisnis Islam, Bandung: Alfabeta, 2003.

Dahlan,Abdul Aziz, Ensiklopedia Hukum Islam, Jakarta: Ichtiar Baru Van Hoeve, 2003.

Djakfar, Muhammad, Etika Bisnis Menangkap Sprit Ajaran Langit dan Pesan Moral Ajaran Bumi, cet. 1, Jakarta: Penebar Plus, 2012.

Harahap, Sofyan Syafri, Akuntansi Islam, Yogyakarta: Bumi Aksara, 2004.

al-Maraghi,Ahmad Musthafa, Tafsir al-Maragbi, cet. 1, Mesir: Musthafa al-Babi alHalabi, 1946.

Muhammad dan Alimin, Etika dan Perlindungan Konsumen dalam Ekonomi Islam, cet. 1, Yogyakarta: BPFE, 2004.

Manzhur, Ibnu, Lisan al-Arabi, Kairo: Dar al-Ma'arif, t.th.

Putra, Ida Bagus Wiyasa, Aspek-aspek. Hukum Perdata Internasional Dalam Transaksi Bisnis Internasional, Bandung: Refika Aditama, 2008 , History of The Arabs, Jakarta: Serambi, 2008.

Philip K. Hitti,History of The Arabs Tenth Edition, New York: Macmillan and CO, 1970.

al-Qurthubi, Abi Abdillah Muhammad bin Ahmad Abi Bakr, Al-Jami' Li Abkami Al-Qur'an, cet. 1, Beirut: Muassasah ar-Risalah, 2006.

Fazlur Rahman, Metode dan Alternatif Neomodernisme Islam Fąlurrabman, Taufik Adnan Amal (Peny), Bandung: Mizan, 1992.

Yahya, Mukhtar, Perpindahan-perpindahan Kekuasaan di Timur Tengah sebelum Labir Agama Islam, Jakarta: Bulan Bintang, 1985.

Irfan, Nurul, Korupsi Dalam Hukum Pidana Islam, cet. 1, Jakarta: AMZAH, 2011.

Rahman, Fazlur, Metode dan Alternatif Neomodernisme Islam Fąlurrahman, 
238 | AL QUDS : Jurnal Studi Alquran dan Hadis vol. 3, no 2, 2019

Shahata, Hussain Hussain, Business Ethics in Islam, Al-Falah Foundation, 1999

Taufik Adnan, (peny), Bandung: Mizan, 1992.

az-Zuhaili, Wahbah, Tafsir al-Munir fi al-Aqidah wa asy-Syari'ah wa al-Manhaj, cet. 10, juz. 11, Damsiq: Dar al-Fikr, 2009. 